\title{
Privatization, Political Risk and Stock Market Development in Emerging Economies
}

\author{
By: Enrico C. Perotti and Pieter van Oijen
}

Working Paper Number 243

March 1999 


\title{
Privatization, Political Risk and Stock Market Development in Emerging Economies
}

\author{
Enrico C. Perotti \\ University of Amsterdam and CEPR
}

Pieter van Oijen

University of Amsterdam

and

Tinbergen Institute, Amsterdam

March 1999

Acknowledgements: We thank Frank Sader and Sheridan Titman for useful comments and the World Bank, Bert Scholtens, and the Master in International Finance Program at the University of Amsterdam for supplying useful data. 


\begin{abstract}
This paper investigates whether privatization in emerging economies has a significant indirect effect on local stock market development through the resolution of political risk. We argue that a sustained privatization program represents a major political test which gradually resolves uncertainty over political commitment to a market-oriented policy as well as to regulatory and private property rights. We present evidence suggesting that progress in privatization is correlated with improvements in perceived political risk. These gains tend to be gradual over the privatization period and are significantly larger in privatizing countries than in nonprivatizing countries, suggesting that the resolution of such risk is endogenous to the privatization process. Our analysis shows further that changes in political risk in general tend to have a strong effect on local stock market development and excess returns in emerging economies, suggesting that political risk is a priced factor. We conclude that the resolution of political risk resulting from successful privatization has been an important source for the rapid growth of stock markets in emerging economies.
\end{abstract}

Keywords: privatization, stock market development, emerging markets, political risk, international investment 


\section{Introduction}

The rapid evolution of capital markets in developing countries has emerged as a major event in recent financial history. Portfolio flows to emerging countries rose tenfold from 1989 to 1995 (IFC 1997) and kept rising until the recent crises. Local stock markets also grew considerably in size. The aggregate market capitalization of the countries classified by the IFC as emerging markets rose from $\$ 488$ billion in 1988 to $\$ 2.225$ billion in 1996. Trading on these stock markets rose in similar magnitude, growing from $\$ 411$ billion to $\$ 1,586$ billion in that period (IFC 1997).

These remarkable developments followed a crisis period when foreign debt and large government deficits had undermined confidence in these economies. A critical policy change in many of these countries has been the establishment of large privatization programs. The known benefits of privatization are a reduction in public debt, improved incentives and efficiency, ${ }^{1}$ and better access to capital. Sales to the private sector led to an inflow of foreign capital and technological transfers (Sader 1995) and have increased integration of local firms in international trade patterns.

The earliest extensive privatization plans were launched in the early eighties in Chile and the UK. These programs were deemed successful and were mimicked by many developing and industrialized countries. From 1980 to 1987, a total of 696 privatization transactions were recorded by Candoy-Sekse (1988), of which 456 took place in developing countries. The importance of sales in developing countries thereafter increased significantly. Privatization revenues climbed from $\$ 2.6$ billion in 1988 to $\$ 25.4$ billion in 1996 , amounting to $\$ 154.5$ billion over the whole period (World Bank 1997, 1998). The privatization database of the World Bank reports more than 3000 transactions in developing countries.

While the privatization process in developing countries has been studied extensively, little attention has been given to its impact on the development of the local equity markets. The coincidence of the emergence of local stock markets and the progress of privatization begs the question to what extend these developments are related. Many emerging countries carried out privatization sales through public offerings on the local stock exchange, leading to significant increases in market capitalization. ${ }^{2}$ However, this direct effect of privatization

\footnotetext{
1 For an assessment of welfare gains from privatization see Galal et al. (1994). For evidence on efficiency gains see Claessens and Djankov (1997) and Boubakri and Cosset (1998).

$2 \quad$ In Chile, by 1993 the three largest companies listed on the exchange were all privatized firms. With a market value of over $\$ 10$ billion, they represented almost $25 \%$ of the market's capitalization. TelMex is easily

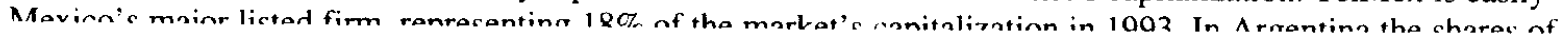


does not account for all of the growth in local stock markets. Total sale revenue of $\$ 154.5$ billion from 1988-1996 represents only a small fraction of the increase in market capitalization over that period. (In addition, many privatization transactions were not carried out through public share issues and some of them took place in countries not classified by the IFC as an emerging market). Thus, although privatization appears to be associated with stock market development, the recent magnitude of local market development by far exceeds their direct impact.

Privatization sales may also produce significant indirect benefits for local stock market development. Listings of large privatized companies provide substantial impact on trading liquidity on the local stock market while at the same time increasing the investment opportunities for local investors to increase their portfolio diversification. These two effects have a positive impact on the risk-sharing function of the market and lead to market deepening. This will particularly hold for developing countries, because the local investors are often not well diversified as a result of capital controls (Levine (1991). ${ }^{3}$

Pagano (1993b) argues that firms seeking listings create an externality for other firms because their shares increase the potential for diversification for all investors. As the original owners incur some flotation costs but do not receive all the benefits of diversification, there will be in general an undersupply of new listings. Privatization may resolve this "low listing trap" by adding diversification possibilities, which in turn encourages both investment and listings by private firms. ${ }^{4}$ In addition, an increase in overall liquidity due to new privatization-related listings can have a self-reinforcing effect on the willingness to hold shares, removing the local market from a «low-liquidity trap». 5

These gains in market deepening and broadening could of course be the result of private listings as well; there is no specific role here of privatization. In this paper we argue that the process of privatization itself, whenever implemented rigorously and consistently, leads to a progressive resolution of regulatory and legal uncertainty, and thus to a resolution of uncertainty over future policy. In particular, successful privatization results in a

YPF, Telecom and Telefonica added up to about 50\% of total market capitalization in 1994. Around 30\% of Malaysia's market capitalization in 1992 was contributed by privatized stocks. (Euromoney 1993,1994).

These local investors tend be less diversified because of capital controls. New listings due to privatization sales reduce the non-systematic risk of a local equity portfolio, and increase the willingness to invest in stocks, leading to higher valuation and trading.

$4 \quad$ An objection to this view is that improving access by domestic investors to foreign financial markets would have an even stronger diversification effect and may thus lead to a similar acceleration in local listings. $5 \quad$ Pagano (1989) offers a theoretical interpretation of the externality effect of liquidity which is parallel in spirit to the diversification argument. In his model, participation by each trader reduces the volatility and 
strengthening of property rights and institutional reliability which broadens the appeal and confidence in equity investment. As such, its impact is particularly relevant for emerging stock markets, whose legal systems are less developed.

Our argument is that prior to a sale, a government is uniquely motivated to establish a solid regulatory framework and to reduce ambiguity concerning private rights. Whenever the government uses the stock market to sell state-owned enterprises, the government also has incentives to facilitate stock market transactions. This may reverse a policy of discouraging private capital issues in order to fund the state's own funding needs. However, this process is neither instantaneous nor irreversible: after the sale there is some potential risk of a policy reversal (Perotti, 1995), particularly as many countries privatize at a time of difficult economic conditions and privatization hits entrenched political constituencies. Only when the commitment to the announced policy is sustained over time, a progressive resolution of legal and political uncertainty takes place. ${ }^{6}$

Equity investment, normally the residual bearer of such risks, thus becomes gradually more attractive as a sustained privatization effort resolves political risk over time. Unlike the other indirect benefits, the resolution of policy uncertainty is specific to privatization sales, and may occur even when privatization does not take place predominantly through public share offerings.

Our argument has two testable implications. First, the recent wave of privatization sales in developing countries should have altered the perceived political risks of these countries considerably, especially if governments have successfully implemented the announced privatization plans. Second, such shifts in political risk tend to affect the attractiveness of equity investments and are therefore related to stock market development.

In this paper we investigate these two implications in order to assess to what extend privatization contributes to the strengthening of local stock markets through the resolution of political risk. We first concentrate on how political risk has developed over the different stages of the privatization programs of 22 emerging economies. We hereby focus on countries that have privatized extensively over a number of years after 1987, and use several quantitative indicators that proxy for our notion of political risk. We then assess the importance of political risk for stock market development in emerging economies by relating

increases the liquidity of the market for all other potential trades, and thereby inducing more entry. This in turn reduces volatility and enhances liquidity, generating the potential for multiple, Pareto-ranked equilibria.

6 For a dynamic model of political risk resolution, see Cherian and Perotti (1998). 
changes in stock market development proxies such as market capitalization, traded value and excess returns to changes in political risk.

We find that many emerging countries have gradually reduced their political risks during the course of sustained privatization. Privatization often starts at a time of declining credibility. Thereafter, perceived political uncertainty is resolved only upon actual implementation of privatization, as opposed to its announcement. In fact, most risk resolution seems to take place as privatization proceeds to its later stage. This suggests that a sustained privatization policy represents a major political test which gradually resolves uncertainty over the political commitment to a market-oriented policy.

The part of our analysis that addresses the importance of political risk for stock market development in emerging countries reveals that such changes in political risk are strongly associated with growth in stock market capitalization, traded value and excess returns. The economic impact of changes in political risk on stock market development appears to be very large. Taken together, these results suggest that the resolution of political risk through sustained privatization has been an important factor in the recent emergence of the stock markets of developing countries.

The relevance of political risk for privatization that we document is consistent with results reported by Jones et al (1998). They show that the share allocation and sale price in IPOs from privatizations are sensitive to political considerations. Our result that political risk resolves gradually is also consistent with the puzzling findings that privatization IPOs appear to outperform matched control groups (Megginson et al 1998). Perotti and Huibers (1998) attribute this result to the greater sensitivity of these stocks to political risk. They confirm that this effect vanishes after the IPO, as political risk gradually declines.

Our analysis on the influence of political risk on stock market development is also related to recent research on the link between the legal institutional framework and corporate finance. LaPorta et al $(1997,1998)$ find that countries with lower quality of legal rules and law enforcement have smaller and narrower capital markets and that the listed firms on their stock markets are characterized by more concentrated ownership. Demirgüç-Kunt and Maksimovic (1998) show that firms in countries with high ratings for the effectiveness of their legal systems are able to grow faster by relying more on external finance. Our analysis contributes to this literature by looking at the relation between stock market development and political risk, which is a broader measure for the quality of the institutional framework that supports the viability of external finance. 
The result that political risk has strong implications for stock market development is an important finding for growth in emerging economies. There is a growing literature that suggests that the development of financial markets support economics growth. Levine and Zervos (1998) find that stock market variables such as market capitalization over GDP, traded value over GDP, and various measures of asset mispricing help predict subsequent economic growth. Several other papers report similar results. ${ }^{7}$ Thus this literature suggests that countries have much to gain from privatization.

Our results have also implications for the analysis of market segmentation, of which political risk is viewed as one of the main causes. Emerging capital markets are believed to have grown largely as a result of decreasing segmentation. But this raises the question of why these markets have become progressively more integrated in the first place. Bekaert (1995) provides evidence that higher levels of political risk are related to higher degrees of market segmentation. Erb, Harvey and Viskanta (1996a) show that expected returns are related to the magnitude of political risk. They find that in both developing and developed countries, the lower the level of political risk, the lower are required stock returns. ${ }^{8}$ Taken together with our results, it seems that political risk is a priced factor for which investors are rewarded and that it strongly affects the local cost of equity, which may have implications for growth.

The outline of the paper is as follows. In Section I we discuss the theoretical basis for the links between privatization, political risk and stock market development. In Section II we present suggestive evidence that successful privatization gradually reduces political risk. Section III addresses the empirical relation between political risk and stock market development in emerging economies. We offer some concluding remarks at the end.

\section{Section I Privatization, Political Risk and Stock Market Development}

Is there something special about privatization sales? Do they provide some indirect benefits for stock market development, regardless of whether or not the privatized shares are floated on the stock exchange? We will argue here that the successful transfer of important

\footnotetext{
$7 \quad$ See Pagano (1993) and Levine (1997) for an overview of the literature.

8 In addition, Erb, Harvey and Viskanta (1996b) and Diamonte, Liew and Stevens (1996) find that changes in political risks are related contemporaneously to stock returns, using several quantitative indicators that proxy for the notion of political risk as outlined above. De Santis and Imrohoroglu (1997) report that emerging financial markets exhibit a higher conditional probability of large price changes than developed stock markets. There may be a role for political risk in explaining this difference in magnitude, as policy changes tend to have a large systemic effect.
} 
enterprises from state to private control has strong implications for the general perception of equity investment in emerging economies.

Privatization is an ideal test for political commitment to market-oriented reforms, as it severely tests the determination of policymakers to resist the political backlash after the sale is completed (Perotti, 1995). It involves a retreat of political forces from the governance of economic activity. As a consequence, politicians used to have discretionary control over firms' activities see their capacity to reallocate resources to their preferred constituencies sharply curtailed. In this shift of control rights to private owners lies the main cause of improved performance of firms under private ownership. ${ }^{9}$ Although in itself may help strengthen the political forces in favor of market-oriented reforms (Bell, 1995; Biais and Perotti, 1997; Schmidt, 1997), no sovereign government can be restrained from altering policy after a sale. Therefore, only a sustained and consistent privatization policy establishes investors' confidence. ${ }^{10}$

In general, a successful privatization program requires institutional changes that contribute significantly to the strengthening of the legal framework underlying equity investment. However, private control and policy reforms must be maintained during any political backlash. As a consequence, market deepening will occur only as confidence builds up over time as a result of the actual progress of privatization and not upon its announcement. Thus our conjecture is that only the actual implementation of the privatization program contributes to the a build up of confidence in a more reliable economic environment, leading to investment and trading. This may explain why privatization may be contemporaneous or even precede successful stock market development. Alternative benefits of privatization, such as improved risk sharing and increased liquidity of the market would supply early, anticipatory effects on market indicators.

There is a tradition of political risk even in developed economies. In the case of the Nippon Telegraph and Telephone sale, the firm was sold as a monopoly but was subsequently broken up, with a large fall in value (over $4 \%$ in one year and $80 \%$ in five years; see Jones et al, 1998). Grandy (1989) offers some historical examples for the US. Political risk represents a particular dilemma for investors in privatization sales and infrastructure projects in emerging economies. Contractual and institutional uncertainty is due in part to a briefer

\footnotetext{
The constitutional guarantee of property rights makes them residual with respect to contractual and legal obligations; thus, legislation may chip away at the owner's entitlement, but it can never fully expropriate them (Perotti, 1995).
} 
experience with development and to a historically more volatile political environment. The result is a less developed legal system; rules and institutions are less established and may be subject to major changes due to administrative shifts.

Political temptation to reverse policy changes after privatization sales is steep because many areas of traditional public ownership represent (traditional) natural monopolies such as utilities and infrastructure. Such industries possess major fixed sunk investments, which however typically produce a steady cash flow of revenues from users. Thus the profits represent considerable rents or quasi rents, which may arouse strong political opposition from, say, users. " Private investment in such industry has always been reluctant because of this heightened risk of de facto expropriation by ex post policy shifts.

An excellent example is the recent case of a highway construction project in Bangkok; a major infrastructure initiative funded by foreign investors, mostly Japanese banks. Once the roads were ready, there was a massive public reaction against the toll rates they charged. Although these fees had been negotiated beforehand, the government forced the roads to be opened and ordered fares to be reduced. The uproar among foreign investors led to a policy reversal, with compensation for a gradual phase-in of the toll rates.

Another example is the case of Tenaga Nasional Bhd, a partially privatized Malaysian power company. In principle, Tenaga had been assured, under a formula agreed with the government in 1993, that it had the right to raise its rates in line with fuel prices and inflation. However, any change in rates had to be approved by the government. While this had been just a formality in the past, the government in May 1995 announced that it would oppose an announced increase in electrical rates. Tenaga's stock fell by $12 \%$ upon the news, as the decision meant a loss of over 80 million dollars a year (Financial Times, April 11 1996).

These examples suggest that privatization by itself does not resolve the question of political risk. After a sale, a populist government may yield to pressure by its constituencies to reallocate value (or maintain entrenched rents) in their favour. Since investors understand these incentives, governments need to strengthen institutional rules protecting equity investment, and to prove over time that they intend to continue doing so.

Thus the privatization process can only progressively establish credibility of announced reform policy, and thus leads only gradually to financial development. In fact, the political 
conflict around privatization sales represents a major test of political will to abandon redistributive policies and move towards market-oriented reform.

Perotti (1995) presents a model of why privatization sales may need to gradual (although securing immediate transfer of control) so that confidence on a stable policy towards privatized companies can be firmly established, thus enhancing revenues; moreover, underpricing may also serve as a complementary signal of commitment. Perotti and Guney (1993) document that sale programs in twelve countries are initially gradual, even when retained stakes are explicitly targeted to be sold over a few years. Proceeds from privatization increase over time, suggesting gradual selling calibrated to build investors confidence. As policy credibility increases, larger initial sales become more common. They also document extensive underpricing, which on average is greater in privatization sales than in initial public offerings (IPO) of private firms, and is especially larger for firms with substantial taxable rents such as utilities which are exposed to greater policy risk. Traditional asymmetric information explanations for underpricing such as Rock (1986) and Grinblatt and Hwang (1989) do not seem appropriate here, since these firms tend to be large and well known relative to private IPOs. Dewenter and Malatesta (1997) confirm that underpricing, while not always higher for privatization sales, is greater for firms subject to greater political risk.

There are other sources of evidence on the impact of privatization on the perception of political risk. Sader (1993) adds privatization sales to a specification originally proposed by Edwards (1990) to explain foreign direct investment flows. His cross-section results over 21 countries indicate that privatization sales are a positive and significant determinant. Moreover, the result is driven by a "macro" rather than a sectorial effect: it is the size of the program to be significant rather than the concentration of sales in specific industries, such as communications, which may be particularly attractive for foreigners. ${ }^{12}$ Openness to foreign investment in privatization is also a good predictor of FDI.

A successful privatization programme may also lead to a resolution of contractual and legal uncertainty relevant to capital markets. This applies for instance to regulation on protection of minority shareholders. ${ }^{13}$ While there may be resistance by established interests

\footnotetext{
12 However, the size of privatization sales in utilities, other traditionally public infrastructures, financial institutions and mining interests, turns out to be correlated with foreign interest. Sader's explanation, with which we concur, is that these are traditionally industries in which populist and nationalist politicians allowed limited the possibilities for foreign and private investment. The decision by the government to privatize in these areas ".. is considered a signal of improvement in the investment climate through reduced government intervention and restrictive regulations" (Sader, 1993).

13 Modigliani and Perotti (1997) show that a strong institutional framework of "rules of the game" is necessary to protect minority investors and thus to promote the development of security markets.
} 
as well as listed firms to a significant improvement in such rules, the necessity for the government to attract foreign and domestic investors requires a reliable security commission, the promotion of greater accounting standards and more transparent disclosure rules, the availability of procedures to contest managerial decisions and appointment, and a reduction in the legal and fiscal rules which typically favour public sector borrowing. Additional steps often involve restrictions on dividend repatriation, foreign ownership and competitive entry.

Finally, it can be argued that following actual privatization, policy reversals (reregulation, taxation, entry deregulation, etc.) are based on arm-length relations, thus subject to much greater public scrutiny. Consequently privatization allows highlighted public debate and increased reliance on legal, as opposed to administrative, recourse. Public debate and heightened visibility of policy choices also contributes to reduced political risk.

In addition, the experience of a large number of new investors leads to increased jurisprudence, and therefore to a progressive resolution of contractual and legal ambiguity, in a sort of "learning by doing". It may even promote the creation of new private arrangements, such as self-regulatory codes or arbitration mechanisms aimed at resolving legal ambiguity. ${ }^{14}$

In conclusion, we conjecture that the experience of privatization forces the creation of rules of the game for security markets as well as the development of an explicit, rule-based regulatory framework, reducing political risk. In the next sections we explore empirically whether the progress of privatization is significantly associated with a reduction in political risk and whether indeed political risk is important for stock market development. For the reasons outlined earlier, we expect political risk resolution to be particularly relevant for developing countries and we therefore focus on emerging markets. This also allows us to understand to what extend the resolution in political that resulted from sustained privatization contributed to the recent boom in emerging stock markets. Section II describes our methodology and analyses the impact of privatization of political risk. Section III assesses the importance of political risk for stock market development in emerging countries.

14 An example of the role of privatization in promoting such private solutions is the Depository Clearing Corporation, a joint venture of Russian and foreign banks and brokers, now tackling the task of updating company share registers, the sole criterion for share ownership by moving registries to Moscow or taking orders to travel to corporate headquarters to record sales. 


\section{Section II The impact of privatization on political risk}

\section{Sample construction and methodology}

We focus on developing countries that are characterized by a minimally developed stock market while at the same time having gone through some privatization experience. To be inclusive, we look at all the countries classified by the IFC as having an emerging stock market. From this group of countries, we selected all markets for which there are data available in the Emerging Stock Markets Factbook from at least 1988 onwards. This leads to a sample of 31 countries. In order to assess how-sustained privatization influenced the development of these stock market through a resolution of political risk, we chose to proceed in two steps.

The first one is to establish how political risk is related to privatization over the medium term. From our sample of 31 countries, we select all those countries that have been engaged in substantial privatization sales for at least four years in the period 1988-1995. We then collect different quantitative measures for the perceived political risk of these countries and look at the evolution over their privatization experience.

Using this criterion, there are 22 countries that can be classified as having a significant privatization policy. ${ }^{15}$ Our requirement of a sufficient history of privatization sales leads to a sample of countries where the privatization process was maintained for at least some time, indicating some degree of sustained privatization. Ideally, one would like to test our predicted relation between privatization and the resolution of political risk by classifying countries as a successful or unsuccessful privatizer. This would require us to judge the quality of each country's privatization policy. We instead use changes in perceived political risk as a summary statistics to avoid making any subjective claims on the quality of privatization policy. While on average the programs in the sample were deemed successful, the sample does include countries for which the privatization process was delayed or slowed down due to political backlash. ${ }^{16}$

Our second step is to test to what extend changes in political risk contribute to stock market development. For this part of the analysis we relate the stock market development in

\footnotetext{
15 There are only a few countries for which inclusion in either of the samples is ambiguous. We neglected Costa Rica and Uruguay for our initial sample of emerging stock markets because of incomplete data for the market capitalization or traded value on the stock market. For Israel, the World reports 15 privatization transactions spread out over 1988 to 1995 . We were unable to obtain privatization data for the years before 1988. Given the low number of transactions and the lack of data we excluded Israel as a privatizing country, but include it in our initial sample of emerging stock markets.

16 Turkey and Venezuela are prime examples during this period.
} 
all of the 31 countries in our initial sample to changes in their perceived political risks. We use growth in market capitalization, traded value and number of listed firms as direct measures of stock market development as well as MSCI World Index adjusted returns.

In order to be able later to assess the timing of the resolution of political risk, we also distinguish four different stages in the privatization process.

Pre-privatization: This period is defined as the two years before the announcement period. It is used so as to measure announcement effects and as benchmark for the privatization period.

Announcement: This period includes the 2 years preceding the first actual sales. By defining a long period we hope to capture the announcement and preparation of privatization.

Early: We define this period as the years of actual start of sales up to the year before the peak in privatization sales takes place.

Late: Includes the year of the peak in privatization revenues as well as all years following the peak, as long as a significant volume of privatization sales continues.

The World Bank database only records privatization transactions that took place since 1988. Therefore, for all countries which privatized in 1988 or 1989 we use other sources to assign the beginning of the privatization program. All countries in our sample continue to privatize up to 1994 . The list of countries and the timing of their privatization stages is given in Table 1 of Appendix 1. ${ }^{17}$

\section{Political risk indicators}

In this section we introduce our quantitative indicators for political risk. The first one is constructed by the Institutional Investor and is published twice a year. The other four were obtained from the commercial agency International Country Risk Guide.

All these are indicators for country risk, of which political risk is only one of the sources. Therefore, not all of these indicators conform as closely to the specific notion of political risk as defined it above. We first briefly expand on how these indicators are constructed and in what sense they are useful for our analysis of political risk.

17 For two countries, we deviate from the definition given above, because the definition would lead to an inappropriate classification of privatization periods. See appendix 1 for a justification for these special cases and for the sources on which we base our classification for countries that were already engaged in privation before the World Bank started to maintain its database. 


\section{$\underline{\text { Institutional Investor Country Credit Rating (CCR) }}$}

This indicator is based on information provided by leading international banks and is constructed and published by the Institutional Investor. Bnkers are surveyed to grade each country (developed as well as developing) on a scale of zero to 100 , where 100 represents the least chance of default. The survey is held every 6 months, includes 75-100 banks reporting their country ratings and was initiated in 1979. There is no formal classification or procedure of how each banker should construct a rating. Hence this measure seems highly subjective.

To shed more light on the factors that bankers take into account in their rating, the Institutional Investor provide bankers with a list of nine factors. The bankers are asked to rank them in order of importance for their credit ratings. For the credit ratings of 1994, debt service was considered the most important factor in rating emerging economies, followed by the political outlook and economic outlook. Table 1 in Appendix 2 provides a list of the rankings of all factors for 1979 and 1994 for emerging countries. The ranking of the factors for 1994 is almost the same as in 1979.

At first sight, the CCR seems strongly related to a government's financial position and less directly related to its political risk. There are several reasons, however, why this indicator provides a useful proxy for political risk. First, the factor «Political Outlook» is ranked high on the list in both years. Second, as we argued above, privatization has implications for the general perception of equity investment. The factors «Inflow of Portfolio Investment» and «Foreign Direct Investment» may therefore capture the bankers' perception on the political risk for each country. Moreover, since the ratings relate to chances of default we expect bankers to be forward looking. Consequently, if portfolio flows or foreign direct investment are expected to improve because of a resolution of political risk (for example, due to announcement of a privatization program), we expect the CCR to respond to this change in perception. Third, the list of factors is provided by the Institutional Investor and therefore may not be very precise in characterizing the key variables in the rating process. ${ }^{18}$ Hence the CCR does not seem to be solely based on the current financial position of the government.

\footnotetext{
18 Quotes in the Institutional Investor citing the motivations of the banker's for grading a country suggest that a government's attitude or ability to sustain a good economic policy are of major concern in the country ratings. For example, «I think Jamaica's rise (in its rating) reflects not only good economic policies but also reduced scepticism about the Prime Ministers intentions, particularly in view of the populist policies during his previous stint as prime minister.» (II Sept 1990, p. 153) or «...I've got a low regard for their ability to follow any economic policy.» (II March 1989, p. 69).
} 
The survey results are published in March and September. The March survey is based on interviews gathered starting in November and thus reflects the opinion prevailing around the end of the year preceding the publication on the political risk rating of the country. ${ }^{19}$

\section{International Country Risk Guide}

The other three indicators were obtained from the commercial agency International Country Risk Guide (ICRG). This series was first constructed for 1984. ICRG classifies country risk into three different categories: political risk, financial risk and economic risk. Each indicator consists of different components of country risk, for which every country receives a score on scale of 1 to 100. These different components are then weighted to construct the country's rating for each category. The components of each of these indicators and the weight of each component for the indicator are given in Table 2 of Appendix 2.

The political risk indicator of ICRG, based on subjective analysis by its analysts, offers the closest relation to our notion of political risk of the three indicators. Especially the first three terms of this indicator are interesting. «Economic Expectations vs. Reality» measures «the perceived gap between popular aspirations for higher standards of living and the ability or willingness of the government to deliver improvements in income and welfare». The second term captures «the ability of government to adopt a suitable and successful economic strategy». "Political leadership» assesses «the viability of the current government based on the degree of stability of the regime and its leader, the probability of the effective survival of the government, and the continuation of its policies if the current leader dies or is replaced». However, the other factors included in this indicator refer to aspects that are not related to our notion of political risk as formulated in section I (for example 'corruption in government', 'political party development' and 'organized religion in politics').

The financial risk indicator is based on quantitative as well as qualitative information. The financial risk indicator has three components that make this indicator worth considering. These are «Repudiation of contracts by the government», «Losses from exchange controls» and «Expropriation of private investments». The other components are less related to our notion of political risk. Also, since this indicator is partially based on historical information, it may not be very forward looking. Therefore, we consider this indicator as a less attractive indicator for the type of political risk we wish to measure compared with the CCR and the ICRG political risk indicator.

19 An editor at the Institutional Investor confirmed that the March ratings are generally received during 
The components of the economic risk indicator have a lot in common with those listed for the Country Credit Risk Rating. An important difference is that it is based solely on quantitative measures of current trends, and that it is not forward looking. Although the economic risk indicator does not appear related to political risk, we include it in our analysis to compare its effect with the country credit rating. If its effect differ substantially from the results obtained using $\mathrm{CCR}$, this provides support for our claim that the CCRs are driven by forward-looking considerations that more closely linked to our notion of political risk.

Table 1 shows the correlation between the yearly growth rates of the various political risk indicators. The correlation between growth rates of the ICRG-political and the ICRGfinancial indicator is quite high, reflecting the political risk content of the latter. Note however that the correlation between the $\mathrm{CCR}$ en the political and financial indicator of the ICRG are rather low. The reason may be that the CCR is the average opinion of many practitioners, while the ICRG-ratings are not. The former measure may therefore aggregate information and contain less idiosyncrasies. Note also that the correlation between CCR and the ICRG-economic risk indicator is not very high compared to the correlation between the political and financial indicator of the ICRG. 


\section{Table 1: Correlation between the annual growth rates of political risk indicators.}

CCR refers to the percentage improvements in the Institutional Investor Country Credit Risk Rating. ICRGPOL, ICRGFIN and ICRGECO refer to percentage improvements in the political, financial and economic risk indicators as constructed by the International Country Risk Guide agency. A description of these indicators is given in the text above.

\begin{tabular}{lcccc}
\hline & CCR & ICRGPO & ICRGFI & ICRGECO \\
\hline CCR & 1.00 & 0.23 & 0.19 & 0.26 \\
ICRGPOL & 0.23 & 1.00 & 0.53 & 0.22 \\
ICRGFIN & 0.19 & 0.53 & 1.00 & 0.20 \\
ICRGECO & 0.26 & 0.22 & 0.20 & 1.00
\end{tabular}

\section{Section II Development of political risk over the privatization programs}

In this section we analyze how political risk has developed over the privatization programs of the 22 privatizing countries in our sample. We are particularly interested in assessing the extent to which sustained privatization has resolved political risk and the timing of the resolution. In doing this, we take the following approach. For our sample of emerging economies that we classified as a having a privatization policy, we document the development of the political risk indicators over the different privatization periods (being the announcement, early and late stage of privatization, and the period before privatization). We then perform simple means tests on whether or not the resolution of political risk differs across privatization periods. Finally, to test whether the resolution in political risk is indeed endogenous to the privatization process, we compare the development of the political risk indicators of the countries that privatize with the improvements in political risk in developing countries that did not engage in privatization.

Table 2 summarizes the behavior of political these periods. Since an increase in each of the indicators represents improvements of political risk, a positive mean growth rate for an indicator in a particular privatization period stands for a decrease in political risk. When looking across the indicators, their seems to be no general pattern in their development. The ICRG political risk indicator and the CCR on average decreased in value in the pre and announcement period, suggesting that countries often privatize in periods of declining credibility; in contrast, they strongly improve in early and late stages of privatization. The ICRG financial risk indicator displays a sharp acceleration during the early phases of privatization and slows down significantly thereafter. The ICRG economic risk indicator shows a strong improvement in the announcement period of privatization, in contrast with the 
ICRG political risk indicator and the CCR. Despite the correlation reported in Table 1, the CCR seems more closely related to the political risk indicator over the privatization process than to the other two measures.

\section{Table 2: Yearly percentage improvements in political risk over privatization periods.}

CCR refers to the percentage improvements in the Institutional Investor Country Credit Risk Rating. ICRGPOL. ICRGFIN and ICRGECO refer to percentage improvements in the political, financial and economic risk indicators as constructed by the International Country Risk Guide agency. A description of these indicators is given in the text above. Average improvements represent the arithmetic means of the improvements in political risk for each period where for each period the yearly improvements are equally weighted.

\begin{tabular}{llrrrr}
\hline & & $\begin{array}{r}\text { Annual change } \\
\%\end{array}$ & $\begin{array}{r}\text { Standard } \\
\text { Deviation }\end{array}$ & Minimum & Maximum \\
\hline CCR & Pre & -2.35 & 10.68 & -41.24 & 25.64 \\
& Announcement & -2.47 & 9.73 & -37.95 & 19.42 \\
& Early & 2.11 & 7.85 & -21.15 & 25.90 \\
& Late & 5.08 & 8.11 & -15.43 & 35.43 \\
\hline \multirow{2}{*}{ ICRGPOL } & Pre & -0.49 & 5.28 & -10.71 & 12.82 \\
& Announcement & -0.07 & 9.07 & -19.44 & 33.33 \\
& Early & 4.51 & 11.49 & -25.00 & 37.50 \\
& Late & 3.28 & 8.33 & -20.00 & 34.15 \\
\hline \multirow{2}{*}{ ICRGFIN } & Pre & 5.09 & 18.39 & -23.08 & 63.64 \\
& Announcement & 5.95 & 17.44 & -19.05 & 66.67 \\
& Early & 8.40 & 15.90 & -25.93 & 47.83 \\
& Late & 2.88 & 11.46 & -14.81 & 76.19 \\
\hline ICRGECO & Pre & -1.50 & 10.96 & -29.27 & 28.89 \\
& Announcement & 2.79 & 9.21 & -16.92 & 23.53 \\
& Early & 3.37 & 11.07 & -21.67 & 41.67 \\
& Late & 2.74 & 7.49 & -14.29 & 31.25 \\
& & & & & \\
\hline
\end{tabular}

The development of the CCRs and ICRG political risk indicator seem to confirm the hypothesis of a gradual resolution of political risk. They do not seem to respond much to the announcement and preparation stage of the programme. In fact, it appears that sales start on average in periods of declining political ratings and that ratings improve only gradually. In other words, there is no immediately gain in political credibility by the establishment of the privatization program. On the other hand, there is on average market development during the process of privatization, which is consistent with the fact that in the average country in our sample the privatization policy was not reversed.

We test whether this pattern is statistically significant by studying whether the improvements in the semi-annual credit rating of Institutional Investor (the CCR) and of the monthly ICRG ratings differ significantly across different privatization periods. The results are given in Table 3. They indicate that the CCRs and the ICRG political risk indicator improve in early and late privatization stages, while there is no evidence of an improvement 
in the announcement stage, suggesting that the announcement of sales per se does not establish much credibility. Moreover, the improvements in the CCR in late stages of privatization are significantly larger than improvements in earlier periods. In contrast, there is no compelling evidence for a particular pattern of development of the financial risk and economic risk indicators over privatization programmes. ${ }^{20}$ Apparently, privatization has a greater effect on political risk than on macroeconomic or institutional characteristics.

\section{Table 3: Difference tests on changes in CCR and ICRG ratings}

Tests are based on semi-annual percentage changes in the Institutional Investor Country Credit Ratings (CCR) and monthly percentage changes in International Country Risk Ratings (ICRG).

\begin{tabular}{|c|c|c|c|}
\hline \multicolumn{2}{|l|}{ Paired T-Test } & \multirow{2}{*}{$\begin{array}{r}\text { Mean Difference } \\
-0.18\end{array}$} & \multirow{2}{*}{$\frac{\text { t-value }}{0.83}$} \\
\hline $\mathrm{CCR}$ & Pre-Ann & & \\
\hline (Semi-annual) & Pre-Early & $* * *-2.40$ & -2.82 \\
\hline & Pre-Late & $* * *-3.70$ & -5.33 \\
\hline & Ann-Early & $* * *-2.22$ & -2.83 \\
\hline & Ann-Late & $* * *-3.52$ & -5.53 \\
\hline & Ear-Late & $* *-1.30$ & -2.08 \\
\hline ICRGPOL & Pre-Ann & -0.01 & -0.08 \\
\hline \multirow[t]{5}{*}{ (Monthly) } & Pre-Early & $* * *-0.40$ & -2.65 \\
\hline & Pre-Late & $* *-0.31$ & -2.49 \\
\hline & Ann-Early & $* * *-0.39$ & -2.68 \\
\hline & Ann-Late & $* *-0.30$ & -2.47 \\
\hline & Ear-Late & 0.09 & 0.75 \\
\hline ICRGFIN & Pre-Ann & -0.01 & -0.06 \\
\hline \multirow[t]{5}{*}{ (Monthly) } & Pre-Early & -0.26 & -1.33 \\
\hline & Pre-Late & 0.13 & 0.67 \\
\hline & Ann-Early & -0.25 & -1.46 \\
\hline & Ann-Late & 0.14 & 0.83 \\
\hline & Ear-Late & $* * 0.40$ & 2.58 \\
\hline ICRGECO & Pre-Ann & -0.38 & -1.30 \\
\hline \multirow[t]{5}{*}{ (Monthly) } & Pre-Early & $*_{-} 0.39$ & -1.66 \\
\hline & Pre-Late & $*_{-} 0.33$ & -1.70 \\
\hline & Ann-Early & -0.01 & -0.04 \\
\hline & Ann-Late & 0.05 & 0.24 \\
\hline & Ear-Late & 0.06 & 0.36 \\
\hline
\end{tabular}

\begin{tabular}{ll}
\hline$* * *$ & denotes significantly different from zero at the $1 \%$ level \\
$* *$ & denotes significantly different from zero at the $5 \%$ level \\
$*$ & denotes significantly different from zero at the $10 \%$ level
\end{tabular}

Of course, the observed pattern in political risk may be due to factors other than privatization. For example, there may have been a change in perceived political risk over the last fifteen years shared by all non-OECD countries, independently of whether or not these 
countries engaged in substantial privatization. ${ }^{21}$ To verify whether these results are due to an overlap in periods together with a common change in perceived political risk for all nonOECD countries, we compare the development of political risk of the countries in the sample with the political risk characteristics of a sample of non privatizing countries.

We selected all countries that are classified as developing countries from the Global Development Finance CD ROM of the World Bank, removing all countries for which the privatization database reported privatization transactions. This resulted in a sample of 24 countries from we constructed a single political risk indicator. The improvements in this indicator are then used as a benchmark to compare each country's political risk performance.

Table 4 provides the results of a paired t-test on the difference in performance between privatizing and non privatizing countries in each privatization period.

\section{Table 4: Difference tests between political risk developments of privatizing and nonprivatizing countries across different privatization periods.}

Tests are based on semi-annual percentage changes in the Institutional Investor Country Credit Ratings (CCR) and monthly percentage changes in International Country Risk Ratings (ICRG).

\begin{tabular}{llrr}
\hline & & $\begin{array}{r}\text { Mean difference } \\
\text { (Privatizing-Benchmark) }\end{array}$ & t-value \\
\hline CCR & Pre & 0.57 & 0.94 \\
(semi-annual) & Announcement & 0.38 & 0.66 \\
& Early & $* * 1.28$ & 2.35 \\
& Late & $* * 1.71$ & 2.48 \\
\hline ICRGPOL & Pre & 0.05 & 0.60 \\
(monthly) & Announcement & -0.00 & -0.00 \\
& Early & $* * * 0.29$ & 2.91 \\
& Late & $* * 0.17$ & -2.32 \\
\hline ICRGFIN & Pre & $* * 0.45$ & 2.50 \\
(monthly) & Announcement & $* * * 0.36$ & 2.67 \\
& Early & $* * * 0.46$ & 4.14 \\
& Late & -0.16 & -1.51 \\
\hline ICRGECO & Pre & -0.24 & -1.12 \\
(monthly) & Announcement & 0.18 & 0.87 \\
& Early & $* * 2.66$ & 1.99 \\
& Late & $* 0.18$ & 1.84 \\
$* * *$ & denotes significantly different from zero at the $1 \%$ level & \\
$* *$ & denotes significantly different from zero at the 5\% level & \\
$*$ & denotes significantly different from zero at the 10\% level &
\end{tabular}

The results of the paired tests offer clear evidence that the two samples of countries does not differ much prior to privatization, the evolution of the CCR risk indicator diverges

21 This possibility is limited by the imperfect time overlap of the various privatization periods. For example, the year 1986 is classified as a year of early privatization for Chile, Jamaica, Malaysia and Mexico while this year falls outside the privatization periods for all other countries. Nevertheless, 1993, 1994 and 1995 are classified as years in the late period of privatization for almost all countries. 
between privatizing and non-privatizing countries in the early and late privatization period ${ }^{22}$. In countries where privatization progresses, the perception of local political risk drops significantly more than for the average emerging country over the same period, suggesting a delayed effect. The ICRG political risk indicator outperformed the non-privatization benchmark in the privatization period, while it is similar in the preceding periods. In the late period, the privatizing countries underperform the benchmark. An explanation may be an exogenous reduction in political instability in high risk countries during the sample years which led to a large drop in the political risk rating spread. It is possible of course that the markets started anticipating future privatization in the non-privatizing countries. The ICRG political risk indicator seems more related to such developments than the CCR. ${ }^{23}$ The financial risk indicator of the privatizing countries outperforms the non-privatization benchmark in all periods (except in the late stage where the difference is not significant).

We conclude that there is apparently some evolution in the perception of political risk in countries engaging in sustained privatization programs relative to other developing countries. This is especially so when political risk is measured by the CCR. Our results support the view that privatization leads to a resolution of political uncertainty. At the same time, it seems that only actual implementation of privatization changes the perception of investors towards political risk. In the next section we analyse how this reduction in political risk favour the development of equity investment in emerging countries.

\section{Section III Political Risk and Stock Market Development}

This section addresses the empirical relation between stock market development and political risk in emerging economies. We study the following indicators of stock market development:

- yearly growth in market capitalization over GNP

- yearly growth in traded value over GNP

- yearly growth in the turnover ratio which is defined as traded value over market capitalization

- yearly growth in the number of listed firms

22 We also performed a nonparametric Wilcoxon test, which provided similar results.

23 For example, Liberia's and Ethiopia's ICRG political risk rating rose by more than $200 \%$ between 1993 and 1995, while over the same period the improvement in their CCR rating was below 50\%. 
- the yearly average of monthly returns, where each monthly return is adjusted for the return of the Morgan Stanley Capital International-world index. ${ }^{24}$

We use the IFC's emerging markets database to obtain these data for our initial sample of 31 countries.

Before we relate stock market development to changes in political risk, we first report how our measures of stock market development fare over the different privatization periods within our sample of 22 privatizing countries. Table 5 reports the summary statistics for these measures over the different privatization phases. ${ }^{25}$

\section{Table 5: Descriptive statistics for changes in stock market development over different privatization periods.}

\begin{tabular}{rlrrrr}
\hline & & $\begin{array}{r}\text { Annual \% } \\
\text { Change }\end{array}$ & $\begin{array}{r}\text { Standard } \\
\text { deviation }\end{array}$ & Minimum & Maximum \\
\hline Capitalization/ & Pre & 42.50 & 101.12 & -74.74 & \\
GNP & Announcement & 51.50 & 131.22 & -65.64 & 658.74 \\
& Early & 45.30 & 88.50 & -66.01 & 402.83 \\
& Late & 24.61 & 58.85 & -65.50 & 233.35 \\
\hline Traded Value/ & Pre & 87.61 & 222.30 & -72.28 & 1072.38 \\
GNPP & Announcement & 109.09 & 325.80 & -68.87 & 1928.48 \\
& Early & 106.63 & 265.21 & -76.90 & 2024.60 \\
& Late & 56.12 & 128.69 & -71.45 & 552.29 \\
\hline Traded Value/ & Pre & 36.53 & 88.89 & -78.64 & 257.35 \\
Capitalization & Announcement & 65.20 & 231.40 & -60.45 & 1418.11 \\
& Early & 32.78 & 77.19 & -77.62 & 322.53 \\
& Late & 24.48 & 69.35 & -72.05 & 433.40 \\
\hline Number & Pre & 5.25 & 27.42 & -14.46 & 162.50 \\
Of Firms & Announcement & 14.17 & 34.56 & -20.87 & 137.50 \\
& Early & 4.98 & 8.03 & -18.82 & 24.14 \\
& Late & 8.94 & 17.32 & -13.33 & 120.00 \\
\hline MSCI Index & Pre & -0.01 & 5.36 & -12.43 & 10.02 \\
Adj. Returns & Announcement & 0.74 & 4.31 & -5.72 & 9.43 \\
& Early & 1.75 & 4.80 & -9.65 & 17.74 \\
& Late & -0.08 & 3.47 & -5.96 & 8.40 \\
& & & & & \\
\hline
\end{tabular}

The data indicate that the development of stock markets in the countries has been radical in all privatization periods. The average yearly growth in traded value over GNP always exceeds $50 \%$ in any privatization period, and is lowest in the late phase of privatization. The pattern over the different privatization periods confirms our earlier claim that the direct effect of privatization from public share issues can only account for a small

\footnotetext{
24 We also used residuals from an estimated ICAPM model as a measure of stock market development. The results are similar to the results reported for the MSCI-world index adjusted returns reported here.

25 For the traded value over GNP ratio, we removed the 1989 observations for Indonesia. In that year, the growth rate of the traded value over GNP equalled an $11700 \%$, which is more than five times as large as the second largest growth rate in the sample.
} 
fraction of the growth of these markets. It is striking that our growth indicators for traded value, capitalization and the number of firms all peak in the announcement period as opposed to the late period, which includes the year of highest privatization sales.

There may be several reasons for the incidence of the peak. First, the countries selected by the IFC as emerging markets are those countries whose stock markets actually did emerge, so there may be a sample selection. These markets often started growing from a very low initial level of market development; small absolute increases in capitalization or traded value then imply very high growth rates. Several countries which started later in the period probably benefited from the rising prices in the leading emerging markets at the time.

Second, the announcement of privatization may induce higher market capitalization, traded value and new listings from the anticipation of risk sharing and liquidity benefits that are expected to result from future privatizations.

Third, it is often the case that while preparing for privatization, some governments list the shares of the state-owned enterprises on the stock exchange before actually selling them. This effect is not too pronounced, however, as it can at most explain the peak for the growth capitalization and the growth in the number of firms; early listings do not increase traded value and decrease the growth in traded value over capitalization. These two measure, however, are also highest during the announcement period.

We now turn to the final part of our analysis. Are changes in political risk important for stock market development in emerging economies? In order to assess this, we use our full sample of 31 emerging stock markets and link stock market development in these countries to changes in political risk. For our non-privatizing countries we use data for the years 19881995. For the countries that we classified earlier as privatizing, we use the same data as described above. We pool the yearly observations into one data set, which produces a sample of about 300 observations. ${ }^{26}$ We then regress our different measures of stock market development on the improvements on political risk, using separate regression for each political risk indicator.

We use three control variables in our regressions: real depreciation vis-à-vis the US dollar, growth of exports per capita and growth of GNP per capita. These factors are assumed to capture general economic developments and to be less directly related (at least contemporaneously) with political risk. The data are obtained from the International Financial Statistics of the IMF and the World Bank Global Development Finance database. We also 
include the yearly privatization sales, scaled by GNP, in the regressions. This term should capture the direct effect of privatization sales as well as the contemporaneous risk sharing and liquidity benefits from share issue privatization.

We perform regressions both with and without country dummies. Only in the regressions for the growth in the number of firms the inclusion of country dummies seems useful. The adjusted R-squared increases by 10 percentage points, reflecting the erratic pattern of the number of listed firms across the different countries. Elsewhere the inclusion worsens the fit of the regression, measured by the adjusted R-squared. Table 6 reports the results of all the regressions, where we include country dummies only in the regression for the growth in number of firms.

Political risk proves to be an important factor for most measures of stock market development. The CCR is significant at the $1 \%$ level for the growth in capitalization over GNP and MSCI-world index adjusted returns. For the traded value over GNP regression, it is significant at the $5 \%$ level and it is borderline significant at the $5 \%$ level for the growth in number firms regression. The ICRG political risk indicator is strongly related to growth in capitalization and traded value, as well as to returns. It is not significant, however, in the regression for the turnover ratio and the growth in the number of firms. The ICRG financial risk indicator is never significant at the $5 \%$ level but is always positively related with stock market development, with significance at the $10 \%$ level in the traded value and in the traded value over capitalization regression. In contrast, the ICRG economic risk indicator, which largely reflects macroeconomic variables, displays no consistency in the sign of its coefficient and is not significant in any of our regressions. Note that the coefficient for the privatization sales over GNP term is insignificant in all regression, and generally negative in CCR and ICRG political risk regressions. This is consistent with our earlier finding that stock market growth has been high for our privatizing countries in the pre-announcement period and in the announcement period, but relatively low in the late period of privatization. ${ }^{27}$

Including country dummies in the regressions generally worsens the overall fit but increases the coefficient of the CCR and ICRG political risk indicators for the capitalization and traded value regressions, with little effect on the significance. The coefficient for the CCR equals 2.3 and 5.0 respectively after including country dummies in these two

\footnotetext{
26 In the regression on excess returns, the size of our sample is reduced to around 190 because the EMDB does not provide return data for all years and for all countries.

$27 \quad$ Excluding privatization sales as a control variable provides similar results for the size and significance levels of the coefficients of the political risk indicators.
} 
regressions while the coefficient for the ICRG political risk indicator increases to 2.0 in the traded value regression.

The regressions also show that stock returns are strongly related to changes in the CCR and ICRG political risk indicator. Although the adjusted R-squares are especially high due to the inclusion of real depreciation, excluding this variable still produces an adjusted $\mathrm{R}$ squared of $11 \%$ for the CCR regression. Our results for the relation between political risk and stock market returns are in line with Diamonte, Liew and Stevens (1996) and Erb, Harvey and Viskanta (1996b). Diamonte et al. find a strong contemporaneous relation between quarterly average returns and quarterly increases or decreases in the ICRG political risk indicator: emerging countries receiving upgrades are characterized by significantly higher average returns than those being down graded. Erb et al, using the same measures of political risk as we do in our analysis, find that this relation between up- and downgrades holds as well for the CCR and the other ICRG ratings. In agreement with our results, these authors also find that among the four indicators, changes in the CCR and the ICRG political risk ratings display the most pronounced correlation with returns.

We checked for the presence of outlier effects by excluding countries with extreme market development patterns (Portugal and Indonesia) from our analysis. The results are similar. In addition, we excluded all observations where the growth in stock market development was more than four standard deviations away from the mean. This reduces the size of the coefficients somewhat, but only affects the statistical significance for the ICRG political risk coefficient in the traded value over GNP regression, which is then borderline significant at the $10 \%$ only. The pattern of significance remains the same for all other regressions. The coefficient for the privatization sales over GNP variable now has the expected positive sign, but it is still insignificant (even at the $10 \%$ level). We also included inflation in the analysis, but the results are almost identical. 


\section{Table 6: Stock market development and political risk.}

The sample consists of all countries classified as an emerging stock market by the IFC and for which the Emerging Stock Markets Factbook provides data on stock market capitalization and traded value on the stock market from 1988 on. This sample consists of 31 countries: the 22 countries we classified as privatizing (see Table 1 of Appendix 1) and 9 additional countries. For the latter group of countries, we use stock market development data from 1988 to 1995. For the countries included in our sample of privatizing, we use stock market development data for the years as reported in Table 1 in Appendix 1. The yearly data for the 31 countries are then pooled into one sample after which we regress our five different measures of stock market development on political risk improvement. As control variables we use growth in GNP per capita, growth in exports per capita, real depreciation and privatization sales over GNP. The regressions for the growth in number of firms include country dummies. t-values are calculated using White heteroskedasticity-consistent standard errors and are in parentheses.

\begin{tabular}{|c|c|c|c|c|}
\hline \multirow{2}{*}{$\begin{array}{l}\text { Panel A } \\
\text { Constant }\end{array}$} & \multicolumn{4}{|c|}{ Dependent Variable: Growth in Market Capitalization over GNP } \\
\hline & $* * 0.25$ & $* * * .24$ & $* * * .23$ & $* * * .26$ \\
\hline & $(5.64)$ & $(5.18)$ & $(5.03)$ & $(5.53)$ \\
\hline Growth in GNP Per Capita & $\begin{array}{r}-.54 \\
(-1.23)\end{array}$ & $\begin{array}{r}-.21 \\
(-.46)\end{array}$ & $\begin{array}{r}-.27 \\
(-.58)\end{array}$ & $\begin{array}{r}-.25 \\
(-.52)\end{array}$ \\
\hline Growth in Exports Per Capita & $\begin{array}{r}* .68 \\
(1.86)\end{array}$ & $\begin{array}{r}* .66 \\
(1.77)\end{array}$ & $\begin{array}{r}.58 \\
(1.60)\end{array}$ & $\begin{array}{r}* .66 \\
(1.80)\end{array}$ \\
\hline Real Depreciation & $\begin{array}{r}* . .56 \\
(-1.72)\end{array}$ & $\begin{array}{r}{ }^{*} . .54 \\
(-1.65)\end{array}$ & $\begin{array}{r}-.45 \\
(-1.30)\end{array}$ & $\begin{array}{r}-.50 \\
(-1.56)\end{array}$ \\
\hline Privatization Sales/GNP & $\begin{array}{l}-2.78 \\
(-.82)\end{array}$ & $\begin{array}{r}.05 \\
(.02)\end{array}$ & $\begin{array}{r}.78 \\
(.27)\end{array}$ & $\begin{array}{r}-.10 \\
(-.03)\end{array}$ \\
\hline \multicolumn{5}{|l|}{ Improvement in: } \\
\hline Country Credit Rating & $\begin{array}{r}* * * 1.89 \\
(3.36)\end{array}$ & & & \\
\hline ICRG Political Risk & & $\begin{array}{r}* * 1.04 \\
(2.59)\end{array}$ & & \\
\hline ICRG Financial Risk & & & $\begin{array}{r}1.02 \\
(1.42)\end{array}$ & \\
\hline ICRG Economic Risk & & & & $\begin{array}{r}.45 \\
(.81)\end{array}$ \\
\hline Adjusted R-sq. & .05 & .02 & .04 & .01 \\
\hline $\begin{array}{l}\text { Prob. F-value } \\
\mathrm{N}\end{array}$ & $\begin{array}{r}.00 \\
301\end{array}$ & $\begin{array}{r}.04 \\
292\end{array}$ & $\begin{array}{r}.01 \\
292\end{array}$ & $\begin{array}{r}.14 \\
292\end{array}$ \\
\hline
\end{tabular}


Panel B

Constant

Growth in GNP Per Capita

Growth in Exports Per Capita

Real Depreciation

Privatization Sales/GNP

Improvement in:

Country Credit Rating

ICRG Political Risk

ICRG Financial Risk

ICRG Economic Risk

(2.42)

$* * 1.65$

(2.03)

$\begin{array}{rrrr}* * * .53 & * * * .49 & * * * .48 & * * * .54 \\ (5.25) & (4.50) & (4.20) & (4.95) \\ -.00 & .63 & .59 & .55 \\ (-.00) & (.53) & (.49) & (.43) \\ * 2.91 & * 2.97 & * 2.84 & * * 2.94 \\ (1.96) & (1.93) & (1.92) & (2.02) \\ -.65 & -.59 & -.40 & -.53 \\ (-1.21) & (-1.07) & (-.72) & (-.98) \\ -10.33 & -4.18 & -3.19 & -4.63 \\ (-.92) & (-.42) & (-.33) & (-.44)\end{array}$

$* 1.79$

(1.82)

Adjusted R-sq.

Prob. F-value

$.04 \quad .02$

.03

.02

$\mathrm{N}$

.04

.02

292

.06

301

292

292

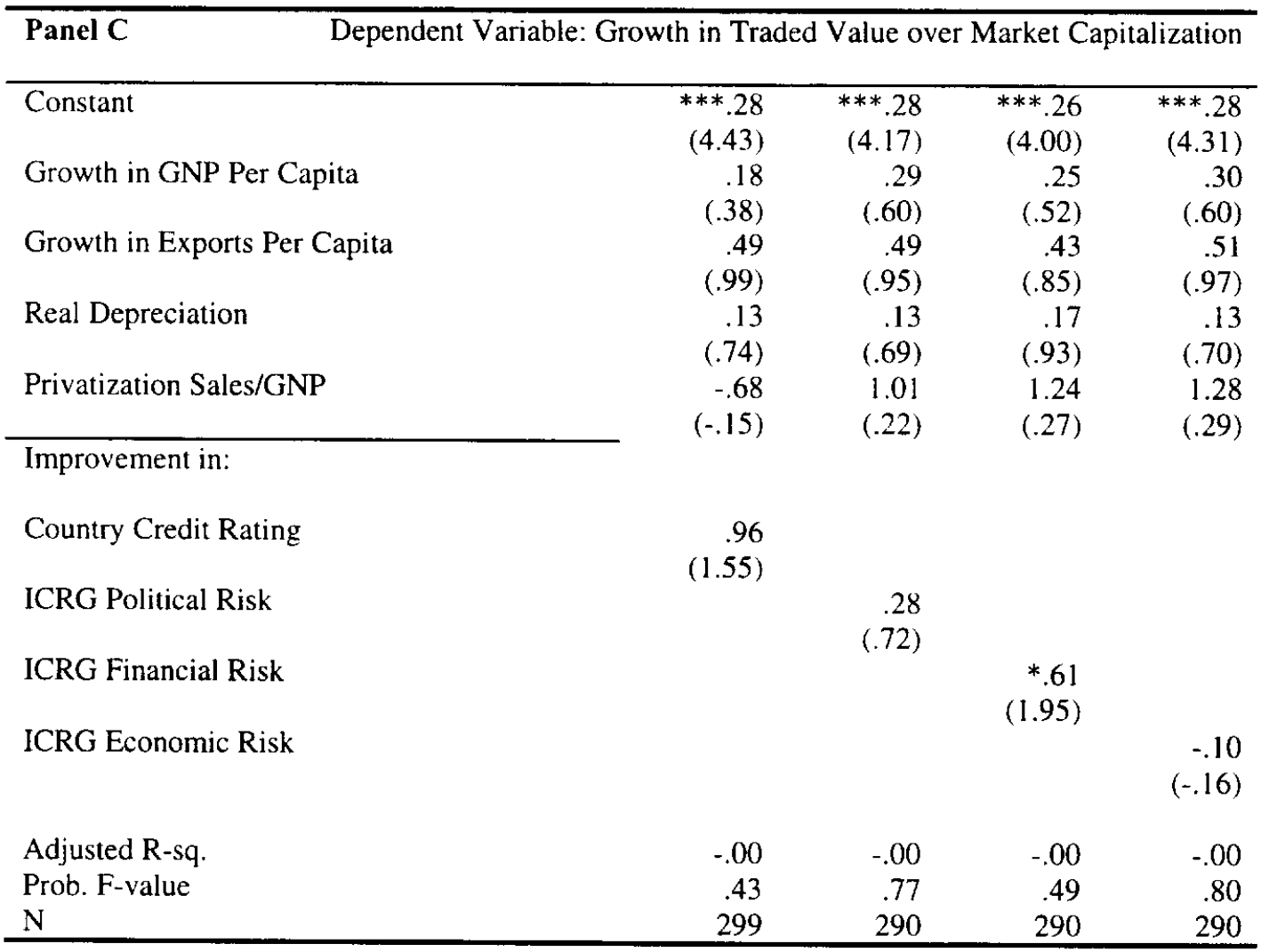




\begin{tabular}{|c|c|c|c|c|}
\hline \multirow{2}{*}{$\begin{array}{l}\text { Panel D } \\
\text { Constant }\end{array}$} & \multicolumn{4}{|c|}{ Dependent Variable: Growth in Number of Firms } \\
\hline & $* * *_{-} .10$ & $* * *-10$ & $* * *-.12$ & $* * *-10$ \\
\hline Growth in GNP Per Capita & $\begin{array}{r}.14 \\
(1.46)\end{array}$ & $\begin{array}{r}* .17 \\
(1.72)\end{array}$ & $\begin{array}{r}* .16 \\
(1.66)\end{array}$ & $\begin{array}{r}* .18 \\
(1.79)\end{array}$ \\
\hline Growth in Exports Per Capita & $\begin{array}{r}.08 \\
(1.13)\end{array}$ & $\begin{array}{r}.08 \\
(1.09)\end{array}$ & $\begin{array}{r}.06 \\
(.84)\end{array}$ & $\begin{array}{r}.10 \\
(1.21)\end{array}$ \\
\hline Real Depreciation & $\begin{array}{r}-.04 \\
(-.88)\end{array}$ & $\begin{array}{r}-.04 \\
(-.74)\end{array}$ & $\begin{array}{r}-.02 \\
(-.35)\end{array}$ & $\begin{array}{r}-.04 \\
(-.78)\end{array}$ \\
\hline Privatization Sales/GNP & $\begin{array}{r}-.04 \\
(-.05)\end{array}$ & $\begin{array}{r}.12 \\
(.14)\end{array}$ & $\begin{array}{r}.34 \\
(.42)\end{array}$ & $\begin{array}{r}.36 \\
(.46)\end{array}$ \\
\hline Improvement in: & & & & \\
\hline Country Credit Rating & $\begin{array}{r}* .19 \\
(1.94)\end{array}$ & & & \\
\hline ICRG Political Risk & & $\begin{array}{r}.15 \\
(1.27)\end{array}$ & & \\
\hline ICRG Financial Risk & & & $\begin{array}{r}.20 \\
(1.56)\end{array}$ & \\
\hline ICRG Economic Risk & & & & $\begin{array}{r}-.07 \\
(-.99)\end{array}$ \\
\hline $\begin{array}{l}\text { Adjusted R-sq. } \\
\text { Prob. F-value } \\
\mathrm{N}\end{array}$ & $\begin{array}{l}.15 \\
.00 \\
294\end{array}$ & $\begin{array}{r}.14 \\
.00 \\
285\end{array}$ & $\begin{array}{r}.15 \\
.00 \\
285\end{array}$ & $\begin{array}{r}.13 \\
.00 \\
285\end{array}$ \\
\hline
\end{tabular}

\begin{tabular}{|c|c|c|c|c|}
\hline \multirow{2}{*}{$\begin{array}{l}\text { Panel E } \\
\text { Constant }\end{array}$} & \multicolumn{4}{|c|}{ Dependent Variable: MSCI-World Index Adjusted Returns } \\
\hline & $\begin{array}{l}-.002 \\
(-.60)\end{array}$ & $\begin{array}{l}-.003 \\
(-.88)\end{array}$ & $\begin{array}{l}-.003 \\
(-.69)\end{array}$ & $\begin{array}{l}-.002 \\
(-.41)\end{array}$ \\
\hline Growth in GNP Per Capita & $\begin{array}{l}-.009 \\
(-.36)\end{array}$ & $\begin{array}{l}.021 \\
(.88)\end{array}$ & $\begin{array}{r}.020 \\
(.79)\end{array}$ & $\begin{array}{r}.016 \\
(.63)\end{array}$ \\
\hline Growth in Exports Per Capita & $\begin{array}{r}.004 \\
(.20)\end{array}$ & $\begin{array}{r}.007 \\
(.31)\end{array}$ & $\begin{array}{r}.007 \\
(.30)\end{array}$ & $\begin{array}{l}.003 \\
(.15)\end{array}$ \\
\hline Real Depreciation & $\begin{array}{r}* * *_{-} .073 \\
(-5.95)\end{array}$ & $\begin{array}{r}* * *-.064 \\
(-4.81)\end{array}$ & $\begin{array}{r}* * * .061 \\
(-4.61)\end{array}$ & $\begin{array}{r}* * *-.061 \\
(-4.46)\end{array}$ \\
\hline Privatization Sales/GNP & $\begin{array}{r}-.32 \\
(-1.13)\end{array}$ & $\begin{array}{r}.005 \\
(.02)\end{array}$ & $\begin{array}{r}.085 \\
(.39)\end{array}$ & $\begin{array}{l}-.030 \\
(-.12)\end{array}$ \\
\hline \multicolumn{5}{|l|}{ Improvement in: } \\
\hline Country Credit Rating & $\begin{array}{r}* * * .160 \\
(3.83)\end{array}$ & & & \\
\hline ICRG Political Risk & & $\begin{array}{r}* * .068 \\
(2.26)\end{array}$ & & \\
\hline ICRG Financial Risk & & & $\begin{array}{r}.029 \\
(1.12)\end{array}$ & \\
\hline ICRG Economic Risk & & & & $\begin{array}{r}.060 \\
(1.46)\end{array}$ \\
\hline Adjusted R-sq. & .23 & .14 & .13 & .14 \\
\hline Prob. F-value & .00 & .00 & .00 & .00 \\
\hline $\mathrm{N}$ & 188 & 182 & 182 & 182 \\
\hline $\begin{array}{ll}* * * & \text { denotes significantly } \\
* * & \text { denotes significantly } \\
* & \text { denotes significantly }\end{array}$ & $\begin{array}{l}\text { from zero at the } 1 \% 1 \\
\text { from zero at the } 5 \% 1 \\
\text { from zero at the } 10 \%\end{array}$ & & & \\
\hline
\end{tabular}


We find the differences in explanatory power among the different political risk indicators intriguing. The qualitative indicators that relate to the political process proved to be most valuable. The more quantitative indicators (ICRG financial and economic risk indicators) provided little evidence for an influence of these factors on market development.

It is possible that the more quantitative indices use conventional, backward-looking economic measures which are less informative on the underlying risk and opportunity factors than perceived risk and confidence. The differences between the significance of the CCR and the ICRG economic risk indicators confirms our earlier claim that the CCR is a valuable measure for the markets' perception of the credibility of government policy.

One may argue that it is possible that privatization only affects stock market development through direct listings and through the risk sharing and liquidity externalities of these listings, and that these benefits are picked up by our political risk indicators. That is, if political risk improves during sustained privatization while it is unimportant for stock market development, it could be that we find that stock market development is related to political risk while it is not caused by political risk.

It appears unlikely that our results are in fact driven by the direct impact of share issue privatization or the risk sharing benefits and liquidity externalities that result from it. There are several strong reasons why our results indicate a direct causality running from political risk to stock market development. First of all, the importance of political risk for stock market development is measured using a sample of privatizers and non-privatizers. Taking into consideration that the sample includes observations from the pre-privatization period for privatizating countries, around $40 \%$ of the observations in our sample are from years in which substantial privatization was not announced or implemented. We also find the gradual pattern in stock market development that our analysis attributes to the gradual resolution of political risk hard to explain only in terms of indirect risk sharing benefits of new listings and increased trading. The stock market is a forward-looking indicator. If market conditions were expected to improve as a direct result of announced privatization sales, prices and trading volume should immediately anticipate these benefits. ${ }^{28}$

Accounting for privatization sales in our analysis allows us to capture the direct effect from share issues as well as any anticipated risk sharing and liquidity benefits which are immediately reflected in market development measures. Interestingly, the inclusion of

\footnotetext{
28 Trading and diversification gains may also be incorporated gradually, of course, if there are fears that the privatization process may be halted or reversed; such concerns do belong to our definition of political and policy risk.
} 
privatization sales hardly affects the coefficients of political risk indicators or their significance. It is therefore unlikely that the political risk indicator simply picks up the effect of privatization sales on market development from channels other than political risk. ${ }^{29}$

In Section II we showed that the Country Credit Risk ratings of the emerging countries in our sample improved considerably after actual privatization sales started, vis á vis developing countries that did not engage in privatization. For the ICRG Political risk indicator we found weaker results.

As a final test, we assess to what extent the development of political risk is related to privatization within our sample of emerging economies.

We use two different proxies for the political risk resolution associated with privatization. The first one is simply privatization sales over GNP. The results in table 8 indicates that privatization has a significant positive impact on political risk

One possible objection is that a contemporaneous linear relation between privatization sales (scaled by GNP) and changes in political risk is not entirely consistent with the hypothesis we have laid out in Section I. Our argument is that privatization has a gradual and contingent impact, as investors watch actual deeds rather than policy statements; thus privatization revenues are not an ideal proxy for the fulfilment of announced policy. Reform policies associated with privatization may be reversed over time; then political risk should be more sensitive to the stock of privatized firms than to the current flow. Thus resolution of risk may be fastest when privatization approaches its latest stage (even though sales may be slowing down) as investor confidence keeps climbing in view of the maintained policy vis-àvis previously privatized firms. Thus we also introduce a dummy which equals one if the observation concerns a country in the early or late stage of its privatization program (see Appendix 1). We include the same control variables we used before. ${ }^{30}$ Table 8 reports the results for the Country Credit Risk Rating and the ICRG Political Risk indicator.

\footnotetext{
29 In turn, excluding the political risk does not affect the coefficient of the privatization sales term either. The inclusion of these variables is somewhat arbitrary. We included them as control variables for macroeconomic developments, which might be correlated with the political risk indicators. We could not think of other exogenous variables that affect political risk as we define it. Ideally, one would like to use such an exogenous variable to test for endogeneity, using a two-stage least squares approach.
} 


\section{Table 8: Privatization and political risk in emerging economies}

The sample consists of all countries classified as an emerging stock market by the IFC and for which the Emerging Stock Markets Factbook provides data on stock market capitalization and traded value on the stock market from 1988 on. This sample consists of 31 countries: the 22 countries we classified as privatizing (see Table 1 of Appendix 1) and 9 additional countries. For the latter group of countries, we use data from 1988 to 1995. For the countries included in our sample of privatizing countries, we use data for the years as reported in Table 1 in Appendix 1 . The yearly data for the 31 countries are then pooled into one sample. The privatization sales dummy equals one if the country is classified as a privatizing country and the year of the observation is during the early or late stage of privatization (see Table 1 of Appendix 1). t-values are calculated using White heteroskedasticity-consistent standard errors and are in parentheses.

\begin{tabular}{|c|c|c|c|c|}
\hline \multicolumn{5}{|c|}{ Dependent Variable: Political Risk } \\
\hline & Country C & it Rating & ICRG F & al Risk \\
\hline Constant & $\begin{array}{r}-.00 \\
(-.44)\end{array}$ & $\begin{array}{r}-.01 \\
(-1.02)\end{array}$ & $\begin{array}{r}* * * .02 \\
(3.22)\end{array}$ & $\begin{array}{l}{ }^{* *} .02 \\
(2.08)\end{array}$ \\
\hline Growth in GNP Per Capita & $* * * .18$ & $* * * .19$ & .01 & .01 \\
\hline Growth in Exports Per Capita & $\begin{array}{r}(4.06) \\
.05 \\
(1.35)\end{array}$ & $\begin{array}{r}(4.42) \\
.04 \\
(1.14)\end{array}$ & $\begin{array}{r}(.24) \\
.05 \\
(130)\end{array}$ & $\begin{array}{r}(.29) \\
.04 \\
(1.14)\end{array}$ \\
\hline Real Depreciation & $\begin{array}{r}.02 \\
(.65) \\
\end{array}$ & $\begin{array}{r}.02 \\
(.81) \\
\end{array}$ & $\begin{array}{r}.02 \\
(1.02) \\
\end{array}$ & $\begin{array}{r}.02 \\
(1.08) \\
\end{array}$ \\
\hline Privatization Sales/GNP & $\begin{array}{r}* * * 1.89 \\
(3.45)\end{array}$ & & $\begin{array}{r}.47 \\
(1.24)\end{array}$ & \\
\hline Privatization Dummy & & $\begin{array}{r}* * * .029 \\
(3.07)\end{array}$ & & $\begin{array}{r}.017 \\
(1.51)\end{array}$ \\
\hline $\begin{array}{l}\text { Adjusted R-sq. } \\
\mathrm{N}\end{array}$ & $\begin{array}{r}.17 \\
306\end{array}$ & $\begin{array}{r}.15 \\
306\end{array}$ & $\begin{array}{l}-.00 \\
298\end{array}$ & $\begin{array}{r}.00 \\
298\end{array}$ \\
\hline $\begin{array}{ll}* * * & \text { denotes significantly } \\
* * & \text { denotes significantly } \\
* & \text { denotes significantly }\end{array}$ & $\begin{array}{l}\text { at the } 1 \% \\
\text { at the } 5 \% \\
\text { at the } 10 \%\end{array}$ & & & \\
\hline
\end{tabular}

The CCR is positively related to the two measures of privatization as the coefficient is significant at the $1 \%$ level in both regressions. The coefficient of the privatization dummy indicates that during the early and late stage of privatization, the CCR rating improves by almost $3 \%$ every year, vis á vis the ratings of the other emerging economies. Combined with the regression results in Table 7 , this implies that the yearly growth rate of market capitalization over GNP increases with 0.055 during privatization (i.e. an increase with 5.5 percentage points). Monthly stock returns are 0.46 percentage points higher during the early and late stage of privatization because of the associated improvements in political risk. ${ }^{31}$

The ICRG Political risk indicator is much weaker related to privatization. The coefficient of the privatization dummy is close to significant at the $10 \%$ and quite large in

31 The regressions show that growth in GNP per capita is positively related to the CCR rating. The regression results in Table 7 are not driven by the correlation between the CCR and growth in GNP per capita. 
size. The lack of strong significance fits in with the mixed results reported in Table 3 in Section II.

We conclude therefore that political risk improvements, correlated with the existence of a sustained privatization program, appear to be an important factor in the rapid development of emerging stock markets. Their economic significance is quite dramatic. The coefficient for the CCR in the traded value regression indicates that if political risk improved by $1 \%$ in a year, we expect that this led to an increase of nearly $4 \%$ for the traded value over GNP! To visualize these implications and to show the implied divergence in stock market development, we took the $20^{\text {th }}$ percentile and $80^{\text {th }}$ percentile value for CCR improvement in each privatization period. We then multiplied these improvements with the coefficients of the CCR variable in the capitalization and traded value regression. Table 9 reports the results of this procedure.

\section{Table 9: Implied development of stock markets over different privatization periods from development of CCR.}

CCR refers to the percentage improvements in the Institutional Investor Country Credit Risk Rating. Calculations are based on the $20^{\text {th }}$ and $80^{\text {th }}$ percentile improvement in political risk in each privatization period and the regression coefficients from Table 6. The percentile scores for the improvement in CCR rating in each period are multiplied by the regression coefficients of the capitalization over GNP and traded value over GNP regressions from Table 6 . The sample averages relate to the sample of privatizing countries (see Table 5).

\begin{tabular}{lrrrr}
\hline & Pre & Announcement & Early & Late \\
\hline $20^{\text {th }}$ percentile CCR improvement & $-8.7 \%$ & $-9.9 \%$ & $-2.9 \%$ & $-0.1 \%$ \\
$80^{\text {th }}$ percentile CCR improvement & $4.3 \%$ & $5.1 \%$ & $6.5 \%$ & $10.1 \%$
\end{tabular}

\begin{tabular}{lrrrr}
\hline \multicolumn{5}{l}{ Regression coefficient implied yearly growth rate in capitalization over GNP: } \\
\hline $20^{\text {th }}$ percentile CCR improvement & $-16.4 \%$ & $-18.7 \%$ & $-5.5 \%$ & $-0.2 \%$ \\
$80^{\text {th }}$ percentile CCR improvement & $8.1 \%$ & $9.6 \%$ & $12.3 \%$ & $19.1 \%$ \\
Sample average (see Table 5) & $42.5 \%$ & $51.5 \%$ & $45.3 \%$ & $24.6 \%$ \\
\hline \multicolumn{5}{l}{} \\
\hline Regression coefficient implied yearly growth rate in traded value over GNP: \\
\hline $20^{\text {th }}$ percentile CCR improvement & $-32.5 \%$ & $-36.9 \%$ & $-10.8 \%$ & $-0.4 \%$ \\
$80^{\text {th }}$ percentile CCR improvement & $16.0 \%$ & $19.0 \%$ & $24.2 \%$ & $37.7 \%$ \\
Sample Average (see Table 5) & $87.6 \%$ & $109.1 \%$ & $106.6 \%$ & $56.2 \%$ \\
\hline
\end{tabular}

The development of the CCR implies a large dispersion in stock market development among the various countries. The average differences in the yearly growth rate of capitalization and traded value over GNP range from 18 to 55 percentage points in any

Excluding this last variable doesn't affect the significance (or size) of the CCR coefficient in the regressions, 
period. ${ }^{32}$ Note, however, that even for an $80^{\text {th }}$ percentile political risk improvement, the predicted development of the stock market is always below the sample average. Of course, political risk did not alone determine the development of these stock markets.

\section{Conclusion}

We have presented evidence that the resolution of political risk through sustained privatization has been an important source for the recent growth in emerging stock markets. It seems that sustained privatization has gradually strengthened the institutional framework by forcing a resolution of political and legal uncertainties which till then hinder equity market development. This ultimately leads to an increase in investor confidence. On average, this process seems to take place gradually as privatization proceeds, with much of the resolution taking place in the late stages of privatization, as opposed to the announcement and preparation period.

An interesting empirical issue is the robustness of our results. Our sample may reflect a set of relatively successful privatizing countries, for which the early 1990s were a late privatization stage, just when emerging stock markets generally performed quite well. However, our argument is that is no coincidence: emerging markets performed so well because they manage to convince many investors of their own reliability through radical economic reforms such as privatization. Ultimately, this is an empirical question which can be addressed at best once a longer historical experience becomes available.

It is possible that privatization, perhaps because it establishes more broad-based ownership, can by itself resolve political risk by helping to overcome political resistance to market reforms and their effect. Biais and Perotti (1997) develop a simple model of how a large privatization program may be designed so as to reduce political risk of future policy reversals. A market-oriented party may increase the probability of being re-elected by implementing a series of underpriced sales, where excess demand is rationed so as to ensure a broad diffusion of shareholding and to reward long term holdings. A wide diffusion of shares may have the effect of shifting the preferences of the middle class. This structural shift in the political equilibrium creates stable political support for market reforms and reduces political risk for equity investment, reducing the equity premium and increasing market capitalization.

other than that in the turnover ratio regression the CCR coefficient is now significant at the $10 \%$ level.

Of course, political risk did not alone determine the development of these stock markets. The implied stock market development from relatively high improvements in political risk predict is still below the sample average. This is consistent with our rather low adjusted r-squares for our regressions. 
Jones et al (1998) find significant empirical support for these conclusions by analysing the pricing and share allocations affiliated with privatization sales.

In our view these observations and the results in our paper point to a strong potential for research developments in the area of political economy and corporate finance. Privatization, just as nationalization, has strong redistributive effects and tends to cause political conflict, whose outcome is most informative for investors. 


\section{Appendix 1: Special Cases in defining the privatization period and a list of the privatizating countries.}

For 5 countries, we deviate from the quantitative definitions of privatization periods given in the text.

Argentina: We put 1989 in the announcement period. In 1989 the newly-elected President Menem immediately announced a privatization plan which already led to sales in 1990 (Sader, 1993)

Brazil: In 1988, there was one large privatization transaction; however, in 1989 and 1990 there were no sales. In 1990 a privatization plan was announced, which took of in 1991 (Sader (1993)). Hence we regard 1990 as part of the announcement period.

Chile: This country has a long tradition of privatization, extending back to the early $70 \mathrm{~s}$. This period consists of two waves of privatization, according to Hachette and Luders (1993). We take the second wave of privatization as our focus of analysis. For privatization sales before 1988 we rely on Hachette and Luders and use 1985 as the start of privatization.

Jamaica: For Jamaica we were unable to obtain information about the precise sales before 1988. We rely here on Leeds (1991) («Privatization Through Public Offerings: Lessons from Two Jamaican Cases» in R. Ramamurti and R. Vernon (eds) Privatization and Control of State-Owned Enterprises, World Bank, Washington DC ) who claims that privatization started off in 1986.

Malaysia: We rely on Sader (1993) and Galal, Jones and Vogelsang (1994) who claim that privatization started in 1985.

Mexico: For Mexico we use Rodriguez (1992) for obtaining privatization sales data before 1988. We neglect the revenues of privatization in 1983 and 1984. Privatization in that period mostly involved liquidation of assets. Revenues were around 40 million and 1 million respectively for those years. In 1985 sales were 113 , and remained above 100 million afterwards. (See Rodriguez 1992).

The countries in our sample of privatizers, and the resulting classification of privatization periods are reported in Table 1. 
Table 1: Sample of countries and their privatization periods

$\begin{array}{lllll} & \text { Pre } & \text { Announcement } & \text { Early } & \text { Late } \\ \text { ARGENTINA } & 87 & 89 & 90 & 92 \\ \text { BANGLADESH } & 85 & 87 & 89 & 93 \\ \text { BRAZIL } & 88 & 90 & 91 & 93 \\ \text { CHILE } & 81 & 83 & 85 & 88 \\ \text { COLOMBIA } & 87 & 89 & 91 & 93 \\ \text { COTE D'IVOIR } & 87 & 89 & 91 & 95 \\ \text { GREECE } & 86 & 88 & 90 & 90 \\ \text { INDIA } & 87 & 89 & 91 & 94 \\ \text { INDONESIA } & 87 & 89 & 91 & 95 \\ \text { JAMAICA } & 82 & 84 & 86 & 89 \\ \text { MALAYSIA } & 81 & 83 & 85 & 92 \\ \text { MEXICO } & 81 & 83 & 85 & 91 \\ \text { NIGERIA } & 85 & 87 & 89 & 93 \\ \text { PAKISTAN } & 86 & 88 & 90 & 94 \\ \text { PERU } & 87 & 89 & 91 & 94 \\ \text { PHILIPPINES } & 85 & 87 & 89 & 93 \\ \text { PORTUGAL } & 85 & 87 & 89 & 92 \\ \text { SRI LANKA } & 85 & 87 & 89 & 92 \\ \text { TUNESIA } & 84 & 86 & 88 & 92 \\ \text { THAILAND } & 88 & 90 & 92 & 93 \\ \text { TURKEY } & 84 & 86 & 88 & 90 \\ \text { VENEZUELA } & 86 & 88 & 90 & 91\end{array}$


Appendix 2: Overview of the Political Risk Indicators

Table 1: Rankings for the importance of factors in Country Credit Risk Ratings.

\begin{tabular}{lll}
\hline Factor & 1979 & 1994 \\
\hline Debt Service & 1 & 1 \\
Political Outlook & 3 & 2 \\
Economic Outlook & 2 & 3 \\
Financial Reserves/Current Account & 4 & 4 \\
Trade Balance & 5 & 5 \\
Foreign Direct Investment & 6 & 6 \\
Fiscal Policy & 9 & 7 \\
Inflow of Portfolio Investment & 8 & 8 \\
Access to Capital Markets & 7 & 9 \\
\hline
\end{tabular}

Source: Erb, Harvey and Viskanta (1996b).

\section{Table 2: Composition of the International Country Risk Guide Indicators}

Political risk indicator Weight

Economic expectations vs. reality .12

Economic planning failures

Political leadership

External conflict

Corruption in government

Military in politics

Organized religion in politics

Law and order tradition

.06

Racial and national tensions

.06

Political terrorism

Civil war risks

Political party development

Quality of bureaucracy

Financial Risk indicator

Loan default or unfavorable loan restructuring $\quad .20$

Delayed payment of supplier's credits $\quad .20$

Repudiation of contracts by government $\quad .20$

Losses from exchange controls $\quad .20$

Expropriation of private investments $\quad .20$

Economic Risk indicator

Inflation $\quad .20$

Debt service as a \% of exports $\quad .20$

International liquidity ratios $\quad .20$

Foreign trade collection experience $\quad .20$

Current account balance as \% of goods and services $\quad .20$

Parallel foreign exchange rate market indicators $\quad .20$ 


\section{References}

Balcerowicz, L. and A. Gelb (1994), «Macropolicies in Transition to a Market Economy: A Three Year Perspective», Proceedings of the World Bank Annual Conference on Development Economics, 21-44.

Bartolini, L. and A. Drazen (1997) »Capital-Account Liberalization as a Signal», American Economic Review 87, 138-54.

Bell, S. (1995) «Privatization Through Broad-Base Ownership Strategies», World Bank Discussion Paper, Washington, DC.

Bekaert, G. (1995), «Market Integration and Investment Barriers in Emerging Equity Markets», The World Bank Economic Review 9, 75-107.

Biais, B. and Perotti, E.C. (1997) «Machiavellian Underpricing«, mimeo, University of Toulouse.

Boubakri, N. and J-C. Cossets (1998) «The Financial and Operating Performance of Newly Privatized Firms: Evidence from Developing Countries», Journal of Finance 53, 1081-1110.

Candoy-Sekse, R. (1988), «Techniques of Privatization of State-Owned Enterprises (Vol III)», World Bank Technical Paper no 90, Washington, DC.

Cherian, J.A. and E.C. Perotti (1998), «Option Pricing and Foreign Investment under Political Risk», mimeo, University of Amsterdam.

Claessens, S. (1995), «The Emergence of Equity Investment in Developing Countries: Overview», The World Bank Economic Review 9, 1-17.

Claessens, S. and S. Djankov (1997), «Politicians and Firms: Evidence from Seven Central and Eastern European Countries», mimeo, World Bank.

Demirguc-Kunt, A. and R. Levine (1994), «The Financial System and Enterprise Reform», World Bank working paper, Washington, DC.

Demirgüç-Kunt, A. and V. Maksimovic (1998), «Law, Finance and Firm Growth», forthcoming in Journal of Finance.

De Santis, G. and S. Imrohoroglu (1997), «Stock Returns and Volatility in Emerging Financial Markets», Journal of International Monev and Finance 16, 561-79.

Dewenter, K.L. and P.H. Malatesta (1997), «Public Offerings of State-owned Enterprises: An International Comparison», Journal of Finance 52, 1659-79. 
Diamonte, R.L., J.M. Liew and R.L. Stevens (1996), «Political Risk in Emerging and Developed Markets» Financial Analysts Journal, 71-76.

Edwards, Sebastian (1990), «Capital Flows, Foreign Direct Investment, and Debt-Equity Swaps in Developing Countries», NBER Working Paper No. 3497.

Erb, C.B. C.R. Harvey and T.E. Viskanta (1996a), «Expected Returns and Volatility in 135 Countries», Journal of Portfolio Management, 32-48.

Erb, C.B. C.R. Harvey and T.E. Viskanta (1996b), «Political Risk, Economic Risk and Financial Risk», Financial Analysts Journal, 29-46.

Euromoney (1993-4), Guide to World Equity Markets, and special supplements.

Galal, A., L. Jones, P. Tandon and I. Vogelsang (1994), Welfare Consequences of Selling Public Enterprises; An Empirical Analysis, World Bank, Washington, DC.

Grandy, Christopher (1989), «Can the Government Be Trusted to Keep Its Part of a Social Contract? New Jersey and the Railways 1825-1888», Journal of Law, Economics and Organization 5, 249-69.

Grinblatt, Mark and Hwang, Chuan Yang, (1989) «Signalling and the Pricing of New Issues», Journal of Finance 44, 393-420.

Hachette, D. and R.J. Lüders (1993), Privatization in Chile: An Economic Appraisal, ICS Press, San Francisco, California.

IFC Review (1994), Private Pension Reform in Latin America, IFC, Washington, DC.

IFC, Emerging Stock Markets Factbook, IFC, Washington DC, Various Issues. Institutional Investor, Various Issues.

Jones, S.L, W.L. Megginson, R.C. Nash and J.M. Netter, (1998) «Share Issue Privatizations as Financial Means to Political Ends», forthcoming in the Journal of Financial Economics .

Laporta, R., F. Lopez-de-Silanes, A. Shleifer and R.W. Vishny (1997), «Legal Determinants of External Finance», Journal of Finance 52, 1131-50.

Laporta, R., F. Lopez-de-Silanes, A. Shleifer and R.W. Vishny (1998), «Law and Finance», Journal of Political Economy 106, 1113-55.

Levine, R. (1991), «Stock Markets, Growth and Tax Policy», Journal of Finance 46, $1445-$ 65 .

Levine, R. (1997), «Financial Development and Economic Growth», Journal of Economic Literature 35, p. 688-726. 
Levine, R. and S. Zervos (1998), «Stock Markets, Banks and Economic Growth», American Economic Review 88, 537-558.

Lüders, R.J. (1991), «Massive Divestiture and Privatization: Lessons from Chile», Contemporary Policy Issues 9, 1-19.

Megginson, W.L., R.C. Nash, J.M. Netter and A.L. Schwartz (1998), « The Long-Run Return to Investors in Share Issue Privatizations», mimeo, University of Georgia.

Modigliani, F. and E.C. Perotti (1997) «Corporate Law Enforcement and the Development of Security Markets: Theory and Evidence», forthcoming in Managerial and Decision Economics.

Pagano, M. (1989), «Endogenous Market Thinness and Stock Price Volatility», Review of Economic Studies 56, 269-288.

Pagano, M. (1993a), «Financial Markets and Growth: An Overview», European Economic Review 37, 613-622.

Pagano, M. (1993b), «The Flotation of Companies on the Stock Market; A Co-ordination Failure Model», European Economic Review 37, 1101-25.

Perotti, E.C. (1995), «Credible Privatization», American Economic Review 85, 847-859.

Perotti, E.C. and S.E. Guney (1993), «The Structure of Privatization Plans», Financial Management 22, 84-98.

Perotti, E.C. and F. Huibers (1998), «The Performance of Privatization Stocks in Emerging Markets: The Role of Political Risk», forthcoming in Advances in Financial Economics.

Rock, K. (1986), "Why New Issues Are Underpriced", Journal of Financial Economics 15, 187-212.

Roland, G. and T. Verdier, 1994, «Privatization in eastern Europe: irreversibility and critical mass effects», Journal of Public Economics, 161-183.

Rodriguez, F. (1992), «The Mexican Privatization Programme: An Economic Analysis», Social and Economic Studies 41, 149-71.

Sader, F. (1993), «Privatization and Foreign Investment in the Developing World 1988-92», World Bank Policy Research Working Paper, Washington, DC

Sader, F. (1995), «Privatizing Public Enterprises and Foreign Investment in Developing Countries, 1988-93», Occasional Paper 5, IFC and World Bank, Washington, DC 
Sanchez, M. and R. Corona (1993), Privatization in Latin America, Inter-American Development Bank, Washington, DC.

Schmidt, Klaus, «The political economy of mass privatization and the risk of expropriation», CEPR Discussion paper, 1997

Singh, A, (1995), «Corporate Financing Patterns in Industrializing Economies», IFC Technical Paper number 2, World Bank, Washington, DC

World Bank (1993), Argentina's Privatization Program; Experience, Issues, and Lessons, World Bank, Washington, DC

World Bank (various years), World Debt Tables; External Finance for Developing Countries, World Bank, Washington DC. 